\title{
Én pasient, to verdener - samhandling mellom sykehjemsleger og sykehusleger
}

\begin{abstract}
BAKGRUNN En stadig sykere pasientpopulasjon på sykehjemmene og overføring av oppgaver til kommunehelsetjenesten stiller store krav til samarbeid mellom første- og annenlinjetjenesten. I artikkelen presenteres sykehjemsleger og sykehuslegers holdning til behandling av sykehjemspasienter og deres beskrivelse av samhandlingen mellom legene på de to nivåene.

MATERIALE OG METODE Denne kvalitative studien ble gjennomført i et norsk fylke i 2011-12. Resultatene er basert på manifest innholdsanalyse av ti fokusgruppeintervjuer med totalt 46 sykehjemsleger fra 26 sykehjem og åtte fokusgruppeintervjuer med 41 sykehusleger fra medisinsk avdeling på sykehuset.
\end{abstract}

RESULTATER Begge legegrupper var ut fra hvert sitt ståsted opptatt av unødvendige innleggelser og overbehandling i sykehus. De hadde svært forskjellig tilnærming til pasientbehandling og formidlet manglende samhandling i behandlingen av sykehjemspasienter. Begge gruppene beskrev påfallende lite kommunikasjon mellom legene i forbindelse med forflytning mellom nivåene.

FORTOLKNING Forutinntatte holdninger, negative erfaringer og mangel på kommunikasjon kan bidra til redusert tillit og hindre god dialog om pasientene. Dette kan føre til både overog underbehandling og feil forventninger. Kommunehelsetjenesten og sykehusene deler ansvaret for hensiktsmessig samhandling og behandling av enkeltpasienter fra sykehjem.

Leger som arbeider med syke, gamle pasienter må forholde seg til mange hensyn, og det kreves ofte samarbeid med andre instanser. Pasientene har krav på faglig forsvarlig og omsorgsfull helsehjelp, som skal være både nyttig og kostnadseffektiv $(1,2)$. Behandling forutsetter som hovedregel informert samtykke, og noen pasienter vil takke nei til behandling (3). Helsedirektoratets veileder Beslutningsprosesser ved begrensning av livsforlengende behandling understreker viktigheten av gode samtaler for å få frem pasientens ønsker og verdier (4).

I Norge finner nesten halvparten av alle dødsfall sted i sykehjem (5). Sykehusinnleggelse skjer hyppig - to norske studier har vist en insidens på i underkant av 600 per 1000 sykehjemsplasser per år $(6,7)$. Helseog omsorgstjenesteloven forplikter kommuner og helseforetak til å inngå samarbeidsavtaler, som blant annet skal omfatte retningslinjer for samarbeid ved innleggelse og utskrivning fra sykehus (8). Veilederen fra Helse- og omsorgsdepartementet sier: «Gjensidig kunnskapsoverføring, dialog og informasjonsutveksling er sentrale samhandlingselementer og helt avgjørende for å sikre gode tjenester og pasientforløp» (9).

I 2009-10 fikk sykehjemmene i et fylke i Norge opplæring i intravenøs behandling for å styrke den medisinskfaglige kompetansen lokalt. Prosjektet ble initiert i forbindelse med samhandlingsreformen og var et samarbeid mellom Medisinsk avdeling ved sykehuset, utviklingssenteret for sykehjem og hjemmetjenester og sykehjemmene i fylket.

Som en del av prosjektet intervjuet vi leger både $\mathrm{i}$ sykehjemmene og $\mathrm{i}$ sykehuset om etiske aspekter ved behandling av sykehjemspasienter. I denne artikkelen presenteres sykehjemsleger og sykehuslegers holdninger til behandling av sykehjemspasienter og deres beskrivelser av og forklaringer på hvordan samhandlingen mellom legene på de to nivåene er når pasientene innlegges $i$ sykehus, under oppholdet og ved utskrivning til sykehjem.

\section{Materiale og metode}

Studien er basert på ti fokusgruppeintervjuer med 46 sykehjemsleger fra 26 sykehjem i perioden juni-desember 2011 og åtte fokusgruppeintervjuer med 41 sykehusleger fra juni-desember 2012.

Anvendelse av fokusgrupper er en kvalitativ forskningsmetode egnet til å få rike beskrivelser av deltagernes erfaringer og dybdekunnskap om komplekse fenomener (10).

\section{Sykehjemslegene}

$\mathrm{Vi}$ inviterte personlig per e-post og telefon alle 57 sykehjemsleger ved 30 sykehjem i fylket til å delta. I tillegg til dem som ble intervjuet var det fem leger som ønsket å bli med, men disse ble ikke inkludert fordi vi etter ti intervjuer opplevde å ha nådd metning. Seks sykehjemsleger ønsket ikke å delta. Det var tre til seks deltakere i hver gruppe.

\author{
Maria Romøren \\ maria.romoren@medisin.uio.no \\ Avdeling for allmennmedisin \\ Institutt for helse og samfunn \\ Universitetet i Oslo \\ og \\ Fagavdelingen \\ Sykehuset i Vestfold
}

Reidar Pedersen

Senter for medisinsk etikk

Institutt for helse og samfunn Universitetet i Oslo

Reidun Førde

Senter for medisinsk etikk Institutt for helse og samfunn Universitetet i Oslo

> Se lederartikkel side 164

Engelsk oversettelse på www.tidsskriftet.no

\section{HOVEDBUDSKAP}

Sykehjemsleger og sykehusleger var fra hvert sitt ståsted opptatt av unødvendige innleggelser og overbehandling av sykehjemspasienter på sykehuset.

Begge legegruppene problematiserte lite samhandling og mangelfull informasjonsutveksling ved innleggelse og utskrivelse fra sykehus.

Mangel på samhandling gjør det vanskelig å sikre riktig behandlingsintensitet tilpasset ønskene til den enkelte pasient og godt samarbeid med de pårørende. 
Vi intervjuet 30 menn og 16 kvinner med 1-38 års erfaring som leger. De arbeidet i sykehjem med 12-169 senger, 1-8 avdelinger og med ulike typer plasser: rehabilitering, kort- og langtidsplasser, palliative plasser og demensavdelinger. Åtte av de 46 legene var ansatt i $100 \%$ og to i $50 \%$ sykehjemslegestilling. De resterende 36 var fastleger med $20 \%$ tilsynslegefunksjon. De fleste av disse delte $20 \%$-stillingen i $40 \%$ tilstedeværelse og $60 \%$ tilgjengelighet ved behov.

\section{Sykehuslegene}

Vi planla og arrangerte ett fokusgruppeintervju med inntil åtte deltagere på hver av de åtte medisinske seksjonene hvor det oftest blir lagt inn eldre pasienter: gastromedisin, geriatri, hematologi, hjertemedisin, infeksjon, lunge, nyre og nevrologisk avdeling.

Vi intervjuet totalt 41 av 82 ansatte leger ved disse seksjonene (17 av 34 leger i spesialisering og 24 av 48 overleger), fire til syv $i$ hvert intervju. Legene hadde fra under ett til 40 års erfaring som leger, og 26 av 41 deltakere var menn. På de tre siste sykehusintervjuene opplevde vi å ha nådd metning.

\section{Intervjuene}

Intervjuene varte $\mathrm{i}$ om lag 60 minutter. RP og RF alternerte som hovedintervjuer, MR deltok på alle intervjuene som kointervjuer. $\mathrm{Vi}$ benyttet en semistrukturert intervjuguide med flere temaer. Disse var blant annet:

- Tema 1: Hvordan tas beslutninger om behandling av alvorlig syke sykehjemspasienter?

- Tema 2: Tvil eller uenighet om behandling og behandlingsnivå

- Tema 3: Dialog og samarbeid mellom sykehjemslegene og sykehuslegene

Det ble også spurt om uenighet mellom nivåene, hva som fungerte og ikke fungerte, $o g$ forslag til forbedring.

\section{Analysen}

Vi fikk mange detaljerte svar på de temaene vi ønsket å belyse og benyttet derfor manifest innholdsanalyse (11). Intervjuet ble diskutert av intervjuerne muntlig umiddelbart, og et skriftlig referat ble diskutert på e-post. Intervjuene ble tatt opp på bånd og transkribert ordrett. Vi benyttet de fire trinnene i systematisk tekstkondensering i bearbeidingen av materialet.

- Forfatterne leste først sykehjemsintervjuene og deretter sykehusintervjuene flere ganger: Først for å få et generelt inntrykk, deretter for å finne hovedtemaer. For analysen som presenteres i denne artikkelen ble intervjuene lest flere ganger med spesiell oppmerksomhet på beskrivelser av samhandling mellom nivåene, og relevant tekst ble markert.
- Alle forfatterne diskuterte utvalgt tekst og ble enige om kategorier, kategoriserte teksten og justerte kategoriene ved behov.

- Deretter ble den kategoriserte teksten gjennomgått systematisk og kondensert, ytterligere analysert og diskutert på nytt. Kategoriene var inspirert av spørsmålene i intervjuguiden og vår tidligere kjennskap til teori og empiri på feltet, og de ble justert underveis $\mathrm{i}$ arbeidet der vi fant frem til mer treffende kategorier.

- Den kondenserte teksten i hver av kategoriene ble sammenfattet til analytisk tekst. Sitatene som er valgt er tydelige, illustrerende og typiske eksempler som utdyper teksten.

Overskriftene på de endelige kategoriene er også brukt til å strukturere resultatdelen: sykehjemsleger og sykehuslegers holdninger til behandling av sykehjemspasienter, samhandling ved innleggelse, under oppholdet og ved utskrivning, forslag til forbedring.

\section{Forskningsetikk}

Studien er godkjent av regional etisk komité Sør-Øst (ref. 2009/1584a-1). Legene fikk muntlig og skriftlig informasjon om studien, inkludert om frivillig deltagelse, mulighet til å trekke seg og garanti om full anonymitet. Skriftlig informert samtykke ble innhentet fra alle deltakerne.

\section{Resultater}

Holdninger til behandling av sykehjemspasienter og samhandling ved innleggelse Sykehjemslegene la hovedvekt på å unngå innleggelser, og mange sa at de journalfører i forkant at pasienten ikke skal på sykehus. De var opptatt av å begrense aktiv, livsforlengende behandling, som de ofte beskrev som både plagsom og uverdig. De beskrev at tilkalte legevaktleger alltid startet behandling eller la inn pasientene - og flere fortalte at de sørget for å være til stede for å unngå dette. Mange hadde opplevd press fra pårørende eller ansatte om å legge inn pasienter.

Mange av sykehjemslegene mente at pasientene ble overbehandlet på sykehuset. Det ble likevel uttrykt forståelse for overbehandling $i$ en akuttsituasjon, blant annet fordi sykehuslegene ikke kjente pasientene og fordi de så for seg at sykehuslegene ikke har tid. Flere var opptatt av å formidle best mulig informasjon om pasienten ved innleggelse.

Sykehjemslegene sa at de ofte blir møtt med skepsis og negativitet fra sykehuslegene de gangene de må legge inn pasienter, selv om det er forskjell på leger og på avdelinger. Noen fortalte at de overdrev alvoret for å slippe diskusjon med sykehuskollegene.
Samhandling? Jeg vil nesten helst slippe à uttale meg om det... (humrer). Nei, det er vel littforskjellig fra de ulike avdelingene. Noen steder er det veldig bra, geriatrisk avdeling og disse kollegene der er enestående å henvende seg til. Men jeg synes dette at vi skal ha en henvisning $i$ hver eneste sving for å komme inn, til tross for at de har skrevet $i$ journalen at vedkommende har åpen retur... så er det et sirkus for å få dem inn hver gang.

Sykehuslegene i studien var fra sitt ståsted opptatt av uhensiktsmessige innleggelser. De tegnet et bilde av gamle, alvorlig syke pasienter i mottagelsen som ikke kan gjøre rede for seg og mangelfull informasjon fra sykehjemmet. De beskrev at pasienten ofte var sendt av sykehjemspersonell eller leger som var utrygge i situasjonen, eventuelt ikke kjente pasienten. Ofte ble pårørende brukt for å få mer opplysninger om pasienten, eller sykepleiere ringte sykehjemmet for å innhente opplysninger.

Legene var sjelden i dialog med sykehjemmet, de mente at det var for tidkrevende og lite fruktbart. Noen av legene sa at kvaliteten på innleggelsesskrivene kunne være god og at dialogen med sykehjemslegene ved innleggelser på dagtid i hovedsak fungerte fint.

Sykehuslegene var kritiske til kvaliteten og kontinuiteten på sykehjemslegetjenesten, samtidig som de hevdet at det var best for den gamle å bli behandlet på sykehjemmet. Selv om de ofte mente sykehuset var feil behandlingsnivå, startet de nesten uten unntak full utredning og behandling. De sa at de drev med overbehandling på sykehuset, men forklarte dette blant annet med at de visste for lite om pasienten og at de gikk ut fra at det var ønsket full behandling siden pasienten var lagt inn.

Det mest utfordrende er manglende opplysninger fra sykehjem, typisk når du har vakt, så kommer det inn en kjempedårlig, nesten død pasient, og du vet ingenting om han, og det eneste du har er kanskje maks en lapp fra sykepleieren på sykehjemmet. Det er utfordrende... Det skjer rett som det er.

Jeg tror, altså, høyere legetilgjengelighet $i$ sykehjemssituasjonen, høyere kompetanse, selvfølgelig må vi gjøre noe med vår kompetanse også, men jeg syns sjelden vi er i dilemmaer hvis vi har vart $i$ kontakt med sykehjemslegen. Det er mer når pasientene legges inn av andre. Eh, så jeg syns kommunikasjon, når vi først er i dialog er lite problematisk, men.. altså, jeg syns veldig sjelden vi er $i$ dialog med sykehjemslegen, jeg. 


\section{Å konferere}

Sykehjemslegene kunne ringe og konferere direkte med overlege ved de ulike medisinske seksjonene både $\mathrm{i}$ forbindelse med og uavhengig av innleggelsen. Denne dialogen var legene på begge nivåer utelukkende positive til. Sykehjemslegene beskrev sykehuslegene som imøtekommende, de fikk svar på medisinskfaglige spørsmål og støtte i mer komplekse saker. De hadde respekt for sykehuslegenes kompetanse.

Sykehuslegene på sin side hadde forståelse for sykehjemslegens behov for råd og støtte og erfarte at det ofte bidrar til at pasientene kan håndteres utenfor sykehus.

\section{Samhandling under oppholdet}

Deltakerne fortalte om lite eller ingen samhandling mellom sykehuslegene og sykehjemslegene mens pasientene var innlagt. Dette ble ikke problematisert i noen av intervjuene.

Ingen av sykehjemslegene hadde opplevd å bli oppringt fra sykehuset for informasjon eller dialog rundt en innlagt pasient. Noen sa det kunne være fint å bli kontaktet, andre sa at slike telefoner kan være forstyrrende i arbeidsdagen.

Sykehuslegene så for seg at legedekningen i sykehjemmene ikke var god nok til at de ville få tak i legen.

\section{Samhandling ved utskrivning}

Sykehjemslegene sa i intervjuene at dialogen ved overflytting til sykehjem var fraværende og opplevde det som et stort problem. Flere mente at sykehuslegene hadde en for lite helhetlig tilnærming til pasienten, at de bare håndterte akutte medisinske tilstander og at pasientene ble for raskt utskrevet. De var opptatt av at det var uetisk å utsette alvorlig syke pasienter med uavklarte tilstander for forflytning og eventuelt reinnleggelse. Noen beskrev også motstand fra sykehusets side mot reinnleggelser.

Informasjonen fra sykehusoppholdet er en rent medisinskfaglig epikrise. Sykehjemslegene ble ikke kontaktet for å diskutere verken medisinskfaglige, praktiske eller etiske spørsmål, selv ikke når svært syke pasienter ble skrevet ut under pågående behandling.

Det er ikke noe problem i seg selv at vi får flyttet over pasienter som skal fortsette med intravenøs behandling, men det som er problemet er når det ikke er avklart, og de ikke er stabilisert på denne behandlingen. Da hadde det vart bedre at de hadde sett at dette her har effekt, pasienten er stabilisert, ting er avklart, hva skal gjøres etter den intravenøse behandlingen, og hvor lenge den skal fortsette. Da er det greit.
Men når pasienten er så dårlig og ingenting avklart, da er det feil synes jeg.

Sykehjemslegene problematiserte også kontrasten mellom avansert sykehusbehandling og sin egen vektlegging av lindrende behandling og pleie i sykehjemmet. De mente at sykehuslegene hadde for lite dialog med pasient og pårørende, spesielt om begrensning av livsforlengende behandling, og at de sjelden ga føringer på behandling og behandlingsnivå etter utskrivning.

Sykehjemslegene måtte informere og realitetsorientere pårørende, korrigere høye forventninger om behandling og bedring, avslutte oppstartet behandling og blir sittende med vanskelige etiske dilemmaer. Noen mente imidlertid at man ved sykehuset var flinke til å informere pårørende og vurdere behandlingsnivå.

... det eneste ordentlige etiske dilemma, det er på ting som er igangsatt fra sykehus ofte, og spørsmål om det skal kontinueres, og forventninger som legges på pårørende, og masse der. $O g$ terminale pasienter som utskrives fra sykehuset med nasogastrisk sonde, og så ringer jeg dem og de kan ikke svare for seg, hva de har tenkt og hvorfor de har gjort dette her. Og det står ikke omtalt $i$ epikrisen, og så skal vi ta standpunkt til hva som skal gjøres med dette her, og... Der er ikke samhandlingen god nok, nei.

Sykehuslegene bekreftet at de aldri tok direkte kontakt med sykehjemslegen ved utskrivning for å informere om eller diskutere pasienten, de sendte en epikrise. Begrunnelsen var mangel på tid. Mange sa at de ser det som sin oppgave å løse en akuttsituasjon, de har ikke tid til å snakke med pasient eller pårørende, og mente det ofte var for tidlig å si noe om prognosen ved utskrivning.

Noen sa at de var bevisst på å gi mer overordnede føringer i epikrisen, andre innrømmet at de kunne bli bedre. Eventuelle anbefalinger handlet oftest om å unngå ny innleggelse, i noen tilfeller å videreformidle vedtak om ikke å igangsett hjerte-lunge-redning. Noen fortalte at de hadde opplevd at budskapet ikke nådde frem til sykehjemmet og at pasienten ble reinnlagt, andre hadde opplevd å få til et fint samarbeid med sykehjemmene.

A skrive en setning $i$ epikrisen er mye fortere gjort enn à ta en telefon, hvor $d u$ først kommer til en eller annen som må hente en eller annen og som har tid, og så sitter du i en samtale $i 15$ minutter, og den tiden har du ofte ikke.
Men, det er klart, hvis vi ikke har vart $i$ god nok dialog med de pårørende, og de ser at nå har pappa fät sonde, og han får mat... For de er $i$ sjokk når de er hos oss, og da er det benekting, og så kommer de på sykehjem, og har en følelse av at sykehuslegene har hatt en optimistisk, aggressiv tilncerming. Og så kommer sykehjemslegen som dødens apostel og fär den rollen, det er jo ikke noe greit? Men jeg tror ikke vi gjør det bevisst, men det kan vare noe i rollene våre, at vi skal ha folk gjennom, hu hei hvor det går, og så kommer de på sykehjemmet, og så går det to uker til, og så er det sykehjemspersonellet som får den der «døden-rollen».

\section{Legenes forslag til forbedring} av samhandling og pasientbehandling

Tanker og innspill fra legene om forbedring kom enten spontant eller når vi spurte om forslag til forbedring av samhandlingen. Sykehjemslegene og sykehuslegene hadde noe ulikt fokus, og svarene handlet både om bedre samhandling og bedre pasientbehandling.

Sykehjemslegene ønsket seg mer hjelp til diagnostikk og behandling. Noen sa at de ønsket å kunne legge inn pasienter for diagnostikk og oppstart av behandling og så overta behandlingen så snart det var forsvarlig. Andre forslag var «poliklinisk øyeblikkelig hjelp-diagnostikk» og tilsyn fra indremedisiner i sykehjemmet.

Sykehuslegene mente at sykehjemmene trengte økte legeressurser slik at flere pasienter kunne behandles der. De sa at sykehjemslegene burde bli bedre til å gjennomføre forhåndssamtaler. De villle ha bedre informasjon og en tydeligere «bestilling» når sykehjemspasienten ble lagt inn. Flere mente at hvis sykehjemslegene i enda større grad hadde ringt for å konferere, kunne det bidra til å unngå sykehusinnleggelser. I tillegg ble det foreslått at sykehjemslegene kunne hospitere på sykehuset for å lære mer om hvordan det jobbes ved de ulike avdelingene.

\section{Diskusjon}

Legene i denne studien opplevde liten grad av samhandling i forbindelse med sykehusinnleggelse av sykehjemspasienter. Samarbeidet er lovpålagt, innholdet er beskrevet i detalj i nasjonale veiledere og lokale samhandlingsavtaler, men det er tydelige utfordringer - på mange plan - med å få til en god dialog i praksis.

Sykehjemslegene og sykehuslegene hadde forskjellig ståsted og ulik innfallsport til samhandling, men det var åpenbare fellestrekk i sykehuslegenes beskrivelser av samhandlingen med sykehjemslegene og omvendt. Det 
var også noe variasjonsbredde internt $\mathrm{i}$ gruppene, slik teksten viser, men dette var klart mindre fremtredende.

\section{Styrker og svakheter}

Vi har intervjuet $80 \%$ av legene ved sykehjemmene i fylket, både fastleger med tilsynslegefunksjon og leger ansatt i sykehjemslegestillinger, ved alle typer avdelinger og alle typer sykehjem. På sykehuset gjennomførte vi intervjuer med leger i alle aktuelle medisinske seksjoner.

Dette er en kvalitativ studie som gir oss kunnskap om legenes opplevelse av samhandlingen. Vi har brukt mengdeord som «mange» og «noen» i teksten for å få frem hvor hovedtyngden av uttalelsene lå og for å vise nyanser og motsetninger i intervjuene. Vi kan ikke generalisere på antall og andeler, men vi mener likevel artikkelen kan gi en adekvat beskrivelse av problemstillingen.

Dette er en delstudie i et større prosjekt der alle sykehjemmene i et fylke fikk opplæring i intravenøs behandling. Intervjuene ble gjennomført etter opplæringen. Målet med opplæringen var ikke å bedre eller endre samhandlingen mellom nivåene, men økt kompetanse i sykehjemmene kan allikevel ha gitt gi bedre rammer og økt interesse for samhandling mellom sykehjem og sykehus. Det vil i så fall bety at lite eller manglende samhandling kan være enda mer utpreget andre steder.

Forskerne i prosjektet var ikke ansvarlige for gjennomføringen av opplæringen på sykehjemmene. Førsteforfatter hadde hovedansvar for innsamlingen av kvantitative og kvalitative data, var en del av prosjektgruppen og hadde tett kontakt med opplæringsteamet. Det var en åpenbar fordel å ha god kjennskap til både opplæringsprosjektet og til de enkelte sykehjemmene, og det var enten andre- eller tredjeforfatter, som ikke var involvert i selve prosjektet, som ledet intervjuene.

I fokusgruppeintervjuer vil det alltid være en mulighet for at informantene tilpasser svaret til hva de tror er forventet eller ønsket av intervjueren eller av de andre informantene. Vi kan ikke utelukke at informanter har overdrevet eller uttalt seg unyansert for å få frem poenger. Motsatt - eventuell selvsensur hos deltagerne vil innebære at samhandlingen er enda mer mangelfull enn resultatene viser. Men vi opplevde at legene var både tydelige og ærlige i sine svar og at det de sa i de forskjellige intervjuene var sammenfallende. Vi tror derfor ikke resultatene er preget av skjevhet av betydning.

\section{Holdninger}

Legene på begge nivåer mente at det $\mathrm{i}$ hovedsak er best for sykehjemspasienter å få behandling i sykehjemmet. De fortalte allike- vel om svært ulike tilnærminger til utredning og behandling i sykehjem og i sykehus. Sykehjemslegene prøvde å unngå innleggelser og begrense livsforlengende behandling - for sykehuslegene var behandlingsimperativet styrende. Mange av sykehjemslegene var kritiske til overbehandling og en for snever medisinskfaglig innretning i sykehusene, mens mange av sykehuslegene var kritiske til kvaliteten og kontinuiteten på legetjenesten i sykehjemmene.

De fleste sykehuslegene erkjente at pasientene blir overbehandlet, men mange mente at ansvaret for begrensning av aktiv behandling og dialog med pasient og pårørende lå hos sykehjemslegen som kjenner pasienten, og de problematiserte i liten grad at behandlingsavklaring må gjøres fortløpende.

Innleggelser gjort av legevaktleger, innleggelser per telefon og andre suboptimale løsninger når sykehjemslegen ikke er til stede, kan se ut til å ha stor innflytelse på sykehuslegenes oppfatning av kvaliteten på og nødvendigheten av innleggelser. Vi har ikke representative data på dette, men von Hofacker og medarbeidere har tidligere vist at mange kritisk syke sykehjemspasienter ikke får en tilstrekkelig medisinsk vurdering før innleggelse i sykehus (12). I en studie med 26 pasienter som døde innen 48 timer etter innleggelse, var to innlagt via legevakten, seks etter telefonkontakt med legevaktlege og åtte innlagt av sykepleier uten kontakt med lege. Det faktiske omfanget av uhensiktsmessige innleggelser er imidlertid antagelig ikke så omfattende $(12,13)$.

\section{Mangel på kontakt}

Begge legegruppene beskrev kommunikasjonssvikt i alle faser av pasientforløpet. Sykehuslegene opplevde at de ofte fikk dårlig informasjon ved innleggelse, sykehjemslegene fikk mangelfull informasjonen ved utskrivning, og det ble rapportert om lite felles tenkning rundt helhetlig behandling og pasientforløp. Sykehuslegene beskrev mangel på tid som en forklaringsfaktor. Samtidig fikk vi inntrykk av at det var lettere for dem å bruke tid og ressurser på utredning og behandling enn å investere i kommunikasjon som trolig kan være besparende og gi mer individualisert pasientbehandling $(4,14,15)$.

Forutinntatte holdninger, negative erfaringer og mangel på kommunikasjon er uheldig for samhandlingen, ødelegger for nødvendig tillit og gjensidighet og øker risikoen for over- og underbehandling. Store forskjeller i oppgaver, mål og incentivstrukturer innenfor de institusjonene legene arbeider i, vil nok også kunne være til hinder for god samhandling. Men innstillinger til pasientbehandling og til hverandre variererte både fra person til person og mellom avdelinger, og det er viktig å merke seg at begge parter beskrev at de hadde god erfaring med samarbeid de gangene de faktisk var i kontakt med hverandre.

\section{Forbedring}

Legenes forslag til bedre samhandling og pasientbehandling handlet om å unngå unødvendige innleggelser, bedre informasjonsutvekslingen og å få bedre kvalitet og kontinuitet i utredning og behandling i sykehjemmene. Disse utfordringene har vært tematisert i Tidsskriftet i 15 år $(16,17)$, og det er foreslått en rekke løsninger, blant annet sykehjemslegevakt (18).

Det er store forskjeller i innleggelsespraksis mellom sykehjem $(7,19)$. Beslutningsprosessene knyttet til potensielle sykehusinnleggelser er komplekse og inkluderer et bredt spekter av faktorer - fra pasiententspesifikke til organisatoriske forhold (19). Det er sannsynlig at bedre legedekning og økt kompetanse i sykehjemsmedisinen vil kunne redusere uheldig innleggelsespraksis: både at unødvendige innleggelser unngås og at flere pasienter som vil ha nytte av det faktisk blir innlagt $(7,13,20)$.

Det er liten tvil om at bedre samhandling ved både potensielle og faktiske overføringer av pasienter mellom sykehjem og sykehus vil gi bedre pasientbehandling på begge nivåer. Økt geriatrisk kompetanse i sykehusene, både i akuttmottakene og avdelingene, har også vært etterspurt lenge (21).

Sykehjemslegene er intervjuet rett før og sykehuslegene rett etter at samhandlingsreformen med sine avtalekrav trådte $\mathrm{i}$ kraft (22). Både nasjonalt og lokalt i kommunehelsetjenesten og i sykehusene har det siden vært jobbet med blant annet avtaler, prosedyrer og elektronisk kommunikasjon.

Vi vet ikke med sikkerhet hvordan reformen har endret samhandlingen om pasienter generelt eller sykehjemspasienter spesielt. Vi tviler allikevel ikke på at resultatene er relevante og viktige også etter at samhandingsreformen er innført. Endring tar tid, og vi vet at det gjenstår mye, som på innholdet $\mathrm{i}$ informasjonsutvekslingen og $\mathrm{i}$ faktisk samarbeid ved overføring av pasientene.

NOVA har rapportert at samhandlingsavtalene ikke har medført vesentlige endringer i opplevd samarbeid mellom partene (23). Helsetilsynets rapport Informasjonen var mangelfull og kom ofte for sent. Oppsummering av landsomfattende tilsyn i 2015 med samhandling om utskrivning av pasienter fra spesialisthelsetjenesten til kommunen konkluderer som følger: «Tilsynet viste også alvorlig svikt i samhandlingen mellom sykehus og kommune. Overføring av informasjon mellom sykehus og kommune var det området hvor fylkesmennene fant flest lovbrudd og forbedringsområder» (24).

En ny undersøkelse fra Riksrevisjonen om ressursutnyttelse og kvalitet i helsetje- 
nesten etter innføringen av samhandlingsreformen bekrefter at samarbeidet mellom primær- og spesialisthelsetjenesten ikke er godt nok (25). Det anbefales i rapporten at Helse- og omsorgsdepartementet vurderer tiltak som kan bedre dette samarbeidet, blant annet når det gjelder kvaliteten på informasjonen som utveksles. Her spiller legene en viktig rolle.

Samhandling er beskrevet som en oppgavefordeling for å nå et felles, omforent mål (22). For sykehjemspasienter mellom sykehjem og sykehus er både veien og målet ofte uavklart og preget av medisinskfaglig og etisk kompleksitet. Sykehjemspasienter som blir akutt syke stiller store krav til kommunikasjon og samhandling, og bedre dialog mellom sykehjem og sykehus er helt nødvendig. Uttrykket «å spille hverandre gode» kunne kanskje inspirere i dette endringsarbeidet. Sykehjemsleger og sykehusleger kunne åpenbart hatt mer nytte og glede av hverandre - til beste for pasienten.

Vi takker Siri Tønnessen for verdifulle bidrag i analysearbeidet.

Prosjektet har fått finansiering fra Helsedirektoratet, Helse Sør-Øst og Universitetet i Oslo.

\section{Maria Romøren (f. 1974)}

er allmennlege og har en postdoktorstilling i et prosjekt om intravenøs behandling i sykehjem. Forfatter har fylt ut ICMJE-skjemaet og oppgir ingen interessekonflikter.

\section{Reidar Pedersen (f. 1973)}

er lege, filosof, professor og leder ved Senter for medisinsk etikk

Forfatter har fylt ut ICMJE-skjemaet og oppgir ingen interessekonflikter.

\section{Reidun Førde (f. 1950)}

er lege og professor i medisinsk etikk ved Senter for medisinsk etikk.

Forfatter har fylt ut ICMJE-skjemaet og oppgir ingen interessekonflikter.

\section{Litteratur}

1. Lov om helsepersonell m.v. https://Lovdata.no/ dokument/NL/lov/1999-07-02-64 (20.6.2016).

2. Forskrift om prioritering av helsetjenester, rett til nødvendig helsehjelp fra spesialisthelsetjenesten, rett til behandling i utlandet og om klagenemnd. https://lovdata.no/dokument/SF/forskrift/ 2000-12-01-1208 (20.6.2016)

3. Lov om pasient- og brukerrettigheter. https://lovdata.no/dokument/NL/lov/ 1999-07-02-63 (20.6.2016).

4. Beslutningsprosesser ved begrensning av livsforlengende behandling. Revidert 2013. Oslo: Helsedirektoratet, 2009

5. Folkehelseinstituttet. Dødsårsaker i Norge. http://statistikkbank.fhi.no/dar/ (20.6.2016)

6. Graverholt B, Riise T, Jamtvedt G et al. Acute hospital admissions among nursing home residents: a population-based observational study. BMC Health Serv Res 2011: 11: 126

7. Krüger K, Jansen K, Grimsmo A et al. Hospital admissions from nursing homes: rates and reasons. Nurs Res Pract 2011; 2011: 247623.

8. Lov om kommunale helse- og omsorgstjenester m.m. https://lovdata.no/dokument/NL/lov/ 2011-06-24-30 (20.6.2016).

9. Samhandlingsreformen - lovpålagte samarbeidsavtaler mellom kommuner og regionale helseforetak/helseforetak. Nasjonal veileder. Oslo: Helseog omsorgsdepartementet, 2012.

10. Malterud K. Fokusgrupper som forskningsmetode for medisin og helsefag. Oslo: Universitetsforlaget 2012.

11. Graneheim UH, Lundman B. Qualitative content analysis in nursing research: concepts, procedures and measures to achieve trustworthiness Nurse Educ Today 2004; 24: 105-12.

12. von Hofacker S, Naalsund P. Iversen GS et al. Akutte innleggelser fra sykehjem til sykehus i livets sluttfase. Tidsskr Nor Legeforen 2010; 130: 1721-4.

13. Wyller TB. For mange eller for få innleggelser? Tidsskr Nor Legeforen 2010: 130: 1702.

14. Pedersen R, Nortvedt $P$, Nordhaug $M$ et al. In quest of justice? Clinical prioritisation in healthcare for the aged. J Med Ethics 2008; 34: 230-5

15. Nortvedt P. Pedersen R, Grøthe KH et al. Clinical prioritisations of healthcare for the aged-professional roles. J Med Ethics 2008; 34: 332-5.

16. Hansen TE, Brekke M. Bedre legetjeneste i sykehjem! Tidsskr Nor Lægeforen 2001; 121: 2360.

17. Rosness TA. De ensomme legene. Tidsskr Nor Legeforen 2016; 136: 103

18. Bakken C. Ønsker legevaktsordning på sykehjem. Tidsskr Nor Legeforen 2008; 128: 361

19. Ågotnes G, Jacobsen FF, Harrington C et al. A critical review of research on hospitalization from nursing homes; what is missing? Ageing Int 2016; 41: $3-16$

20. Ranhoff AH, Linnsund JM. Når skal sykehjemspasienter innlegges i sykehus? Tidsskr Nor Lægeforen 2005; 125: 1844-7

21. Bakke HK. Helseforetakene må prioritere geriatrien. Tidsskr Nor Lægeforen 2004; 124: 2523.

22. Meld. St 47 (2008-2009). Samhandlingsreformen Rett behandling - på rett sted - til rett tid. https://www.regjeringen.no/no/dokumenter/ stmeld-nr-47-2008-2009-/id567201/sec1 (24.11.2016).

23. Martens CT, Veenstra M. Samarbeidsavtaler mellom helseforetak og kommune. Fra dialog til avviksmelding? NOVA-rapport nr. 9/15. Oslo: Norsk institutt for forskning om oppvekst, velferd og aldring, 2015.

24. Informasjonen var mangelfull og kom ofte for sent Oppsummering av landsomfattende tilsyn i 2015 med samhandling om utskrivning av pasienter fra spesialisthelsetjenesten til kommunen. Oslo: Helsetilsynet, 2016 .

25. Riksrevisjonens undersøkelse av ressursutnyttelse og kvalitet i helsetjenesten etter innføringen av samhandlingsreformen. Oslo: Riksrevisjonen, 2016

Mottatt 2.2. 2016, første revisjon innsendt 20.6. 2016, godkjent 24.11. 2016. Redaktør: Tor Rosness. 